University of Nebraska - Lincoln

DigitalCommons@University of Nebraska - Lincoln

Publications, Agencies and Staff of the U.S.

Department of Commerce

U.S. Department of Commerce

2012

\title{
Responses of Antarctic pack-ice seals to environmental change and increasing krill fishing
}

\author{
Jaume Forcada \\ Natural Environment Research Council, jfor@bas.ac.uk \\ Philip N. Trathan \\ Natural Environment Research Council \\ Peter L. Boveng \\ Alaska Fisheries Science Center \\ Ian L. Boyd \\ University of St. Andrews \\ Jennifer M. Burns \\ University of Alaska \\ See next page for additional authors
}

Follow this and additional works at: https://digitalcommons.unl.edu/usdeptcommercepub

Part of the Environmental Sciences Commons

Forcada, Jaume; Trathan, Philip N.; Boveng, Peter L.; Boyd, Ian L.; Burns, Jennifer M.; Costa, Daniel P.; Fedak, Michael; Rogers, Tracey L.; and Southwell, Colin J., "Responses of Antarctic pack-ice seals to environmental change and increasing krill fishing" (2012). Publications, Agencies and Staff of the U.S. Department of Commerce. 338.

https://digitalcommons.unl.edu/usdeptcommercepub/338

This Article is brought to you for free and open access by the U.S. Department of Commerce at DigitalCommons@University of Nebraska - Lincoln. It has been accepted for inclusion in Publications, Agencies and Staff of the U.S. Department of Commerce by an authorized administrator of DigitalCommons@University of Nebraska - Lincoln. 


\section{Authors}

Jaume Forcada, Philip N. Trathan, Peter L. Boveng, Ian L. Boyd, Jennifer M. Burns, Daniel P. Costa, Michael Fedak, Tracey L. Rogers, and Colin J. Southwell 


\title{
Responses of Antarctic pack-ice seals to environmental change and increasing krill fishing
}

\author{
Jaume Forcada $^{\mathrm{a}, *}$, Philip N. Trathan ${ }^{\mathrm{a}}$, Peter L. Boveng ${ }^{\mathrm{b}}$, Ian L. Boyd ${ }^{\mathrm{c}}$, Jennifer M. Burns ${ }^{\mathrm{d}}$, \\ Daniel P. Costa ${ }^{\mathrm{e}}$, Michael Fedak ${ }^{\mathrm{c}}$, Tracey L. Rogers ${ }^{\mathrm{f}}$, Colin J. Southwell ${ }^{\mathrm{g}}$ \\ ${ }^{a}$ British Antarctic Survey, Natural Environment Research Council, Madingley Road, Cambridge CB3 OET, UK \\ ${ }^{\mathrm{b}}$ National Marine Mammal Laboratory, Alaska Fisheries Science Center, National Marine Fisheries Service, NOAA, 7600 Sand Point Way NE, Seattle, WA 98115, USA \\ ' Sea Mammal Research Unit, Scottish Oceans Institute, University of St. Andrews, St. Andrews KY16 8LB, UK \\ ${ }^{\mathrm{d}}$ Department of Biological Sciences, University of Alaska, Anchorage, AK 99508, USA \\ e Long Marine Laboratory, University of California, 100 Shaffer Road, Santa Cruz, CA 95060, USA \\ ${ }_{\mathrm{f}}^{\mathrm{f}}$ Evolution and Ecology Research Centre, School of BEES, University of New South Wales, Australia \\ ${ }^{\mathrm{g}}$ Australian Antarctic Division, Department of Environment, Water, Heritage and the Arts, 203 Channel Highway, Kingston, Tasmania 7050, Australia
}

\section{A R T I C L E I N F O}

\section{Article history:}

Received 11 October 2011

Received in revised form 23 January 2012

Accepted 1 February 2012

Available online 6 April 2012

\section{Keywords:}

Antarctic pack-ice seals

Climate change

Fisheries management

Habitat change

Krill

Uncertainty

\begin{abstract}
A B S T R A C T
The compound effects of changing habitats, ecosystem interactions, and fishing practices have implications for the management of Antarctic krill and conservation of its predators. For Antarctic pack-ice seals, an important group of krill predators, we estimate the density and krill consumption in the West Antarctic Peninsula (WAP)-Western Weddell Sea area, the main fishery region; and we consider long-term changes in suitable pack-ice habitat, increased fishing pressure and potential krill declines based upon predictions from declines in sea ice cover. More than 3 million crabeater seals consumed over 12 million tonnes of krill each year. This was approximately $17 \%$ of the krill standing stock. The highest densities of pack ice seals where found in the WAP, including in its small-scale fishery management areas, where apparently suitable seal habitat has declined by $21-28 \%$ over a 30 year period, where krill density is likely to have declined, and fishing has increased. The highest seal density was found in the Marguerite Bay area which is a source of krill for the Antarctic Peninsula and elsewhere. Significant sea-ice loss since 1979 has already occurred, leading to open water and possible expansion for the fishery in the future. These factors may combine to potentially reduce food for pack ice seals. Therefore, high uncertainty in krill and seal stock trends and in their environmental drivers call for a precautionary management of the krill fishery, in the absence of survey data to support management based on specific conservation objectives for pack-ice seals.
\end{abstract}

(c) 2012 Elsevier Ltd. All rights reserved.

\section{Introduction}

Antarctic krill (Euphausia superba) is most abundant in the Scotia Sea, Antarctic Peninsula and Western Weddell Sea regions where more than half of the world's biomass is thought to be present (Atkinson et al., 2009). It is a keystone species that sustains millions of predators, and a fishery that operates almost exclusively in this area but is currently thought to under-exploit the potential yield of the stock (Nicol et al., 2011). Increasing habitat deterioration, ecosystem fluctuation and new fishing practices combine to create a high level of uncertainty that needs to be incorporated within fisheries management. In this region, a specific management objective is to prevent irreversible declines in krill-dependent predators and this includes the crabeater seals (Lobodon carcinophaga).

\footnotetext{
* Corresponding author. Tel.: +44 (0)1223 221326; fax: +44 (0)1223 221259

E-mail address: jfor@bas.ac.uk (J. Forcada).
}

In the Scotia Sea-Weddell Sea region, pack-ice seals and specifically crabeater seals have been identified as the major krill consumers (CCAMLR, 2008); over 90\% of crabeater seals' diet is estimated to be krill. Krill is also important for leopard seals (Hydrurga leptonyx), but may be less important for Weddell (Leptonychotes weddelli) and Ross seals (Ommatophoca rossii) (Laws, 1984; Øristland, 1977; Siniff and Stone, 1985). In recent decades, rapid environmental change (Meredith and King, 2005; Parkinson, 2004; Stammerjohn et al., 2008; Whitehouse et al., 2008) is having a significant effect on some populations of different krill predators (Ducklow et al., 2007; Forcada et al., 2006, 2008; Fraser and Hofmann, 2003; Trivelpece et al., 2011). For pack-ice seals, climate change leads to sea ice loss, which reduces suitable breeding and resting habitat. Sea ice also affords protection from predators (Siniff et al., 2008; Costa et al., 2010), and its loss also increases the distance to areas that concentrate prey (Burns et al., 2004; Southwell et al., 2005). Sea ice loss has also been associated with declines in krill biomass (Atkinson et al., 2004), particularly in the West Antarctic Peninsula region, where predator responses to regional 
warming over recent decades suggest a less predictable krill supply (Fraser and Hofmann, 2003; Trivelpece et al., 2011).

The loss of winter sea ice in the Antarctic Peninsula has also allowed a temporal and geographical expansion of the krill fishery, coupled with new markets and technologies (Kawaguchi et al., 2009; Nicol et al., 2011). Consequently, total catches and catch rates per vessel have increased significantly over the last decade (CCAMLR, 2011; Nicol et al., 2011), especially in FAO management Area 48.1 which includes parts of the Scotia Sea, the Western Weddell Sea (WWS), and the WAP (Fig. 1). Even though current fishing is thought to be sustainable, because catches are extracted mainly from coastal areas where predators have a limited capacity to shift distribution in response to local depletion by a fishery (Trivelpece et al., 2011), there are concerns about the effects of the fishery on krill populations and krill predators (e.g. Schiermeier, 2010). While a procedure for small-scale area management has been advocated (Hewitt et al., 2004), it does not take into account uncertainty associated with observed sea ice loss or a potentially declining krill biomass and the consequences for predators.

In this paper we consider the consequences of climate change and increased krill fishing for Antarctic pack-ice seals. We: (1) report the density of pack-ice seals in the WAP-WWS area in relation to the sea-ice environment, at a resolution compatible with the krill fishery small scale management areas; (2) address the longterm change, from 1979 to 2011, in suitable pack-ice seal habitat; (3) relate estimated krill consumption of pack-ice seals to available biomass, as estimated in a synoptic survey in 2000 , and commercial extraction in Area 48.1; and (4) address the regional sensitivity of pack-ice seals to trends in the physical-biological environment and the fishery operation.

\section{Materials and methods}

\subsection{Study area and data collection}

The study area lies between $90^{\circ}$ and $30^{\circ} \mathrm{W}$ and $80^{\circ}$ and $60^{\circ} \mathrm{S}$ (Fig. 1). Particular sub-areas of interest were: the WAP and
WWS, separated at the northernmost tip of the Antarctic Peninsula (approximately $63.5^{\circ} \mathrm{S}$ ); the Marguerite Bay area (MBA), between $78^{\circ}$ and $66^{\circ} \mathrm{W}$ and $70-66.5^{\circ} \mathrm{S}$; and FAO Area 48.1, which includes specific Small Scale Management Units (SSMUs; Hewitt et al., 2004), where the krill fishery operates. Seal habitat was considered to be the pack-ice, limited by the ice-edge and areas covered by fast-ice, shelf-ice, continental-ice or ice-free land. The ice edge was defined using the bootstrap algorithm for sea ice concentrations from Nimbus-7 SMMR and DMSP SSM/I (Comiso, 1999), producing a composite sea ice map for the survey period with $0.2^{\circ}$ lat/ lon grid cell resolution.

Pack-ice seal line-transect data were collected in an aerial survey conducted as the UK contribution to the Antarctic Pack Ice Seals (APIS) programme (Anonymous, 1995). The survey occurred between 22 and 29 January 1999, using a De Havilland Canada DHC-6 Series 300 Twin Otter aircraft operated by the British Antarctic Survey. Transects were placed to effectively sample the pack-ice habitat according to its configuration on the West and East sides of the Antarctic Peninsula (Fig. 1), given the range limits and operational capacity of the aircraft. Transects did not follow a systematic design.

Observers at each side of the aircraft searched for seals hauled out on ice, measuring perpendicular distances to the trackline from the aircraft to sightings of seal aggregations while flying at constant speed and altitude. A semi-automated system (Southwell et al., 2002) logged the data to ensure maximum sighting efficiency. In one transect, paired observers searched independently on the same side of the aircraft to collect double observer data to estimate detectability bias on the trackline. Effects of observer $(o b)$, group size (gs), and species (s) were collected to model heterogeneity in detectability. Species had four categories: cs crabeater, ws Weddell, ls leopard, and us unidentified seal; Ross seal sightings were only confirmed on one occasion and thus were excluded from the analysis. Visibility directly underneath the flying path was obstructed within the first $100 \mathrm{~m}$ to each side of the aircraft.

Year round seal activity data with daily resolution, partitioned when possible as duration of haul-out $(h)$, diving $(d)$, and at the

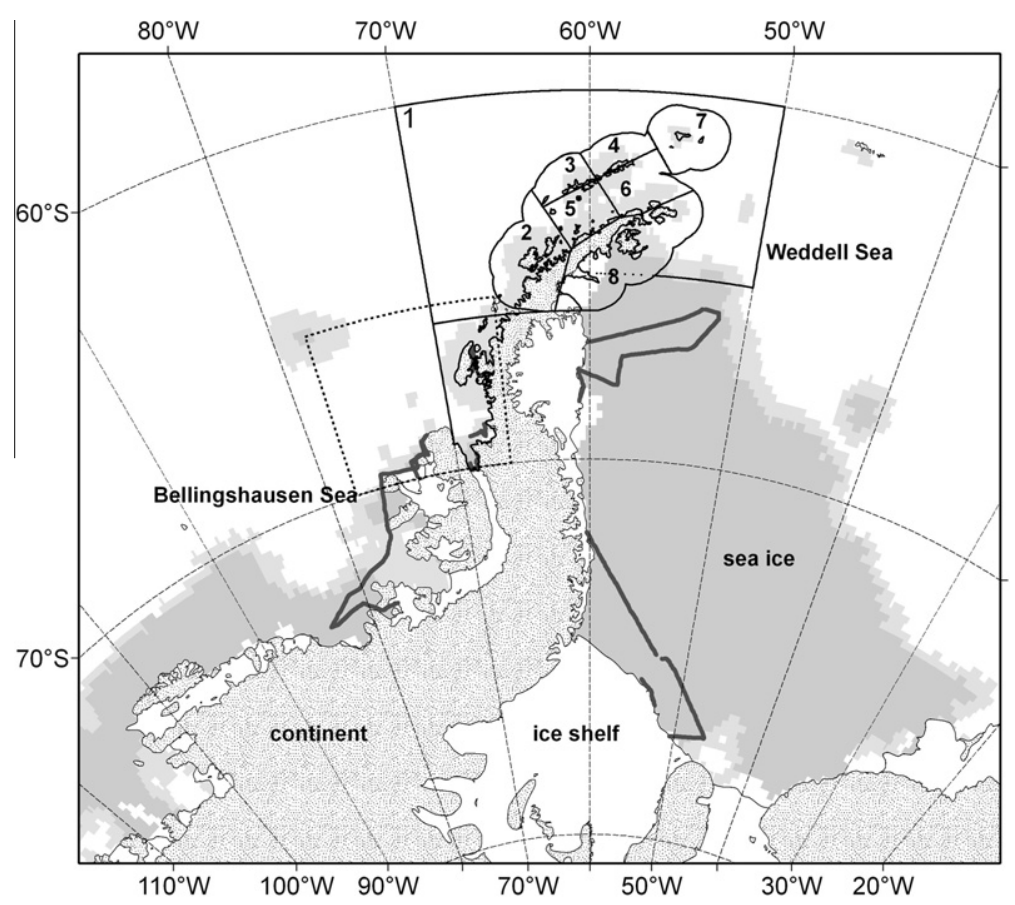

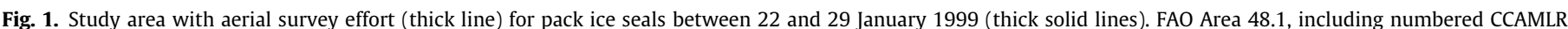

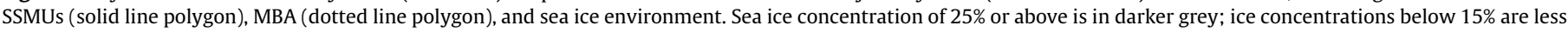
reliable. FAO Area 48.1 extends to $70^{\circ} \mathrm{S}$ including the Marguerite Bay area, but with a lower longitudinal extent than the dotted area delimitation. 
surface $(o)$, were collected to model haul out probability to correct on-ice abundance estimates, and activity budgets to model seal bioenergetics. Satellite-linked dive recorders (SDRs) and satellite relay data loggers (SRDLs) were attached to seals in different research projects: SRDL data from 34 crabeater seals in the Marguerite Bay area in 2001 and 2002 (Burns et al., 2004; Costa et al., 2010); SDR data from 24 crabeater seals from East Antarctica (Southwell, 2005); and SDR data from 11 leopard seals in East Antarctica (Southwell et al., 2008b; Rogers et al., 2005). SRDL data from 9 Weddell seals were collected during research cruises of the MBA (Costa et al., 2010) and central Southern Weddell Sea in 2007 (Nicholls et al., 2008).

\subsection{Spatial density and abundance analysis}

We estimated absolute seal density and abundance with the count method for line transect data (Hedley and Buckland, 2004). Transects were divided into approximately 5-km long segments and in the $i$ th segment, the number of seals of species $s \hat{n}_{i}^{s}$ was $\sum_{j} n_{i j}^{s} /\left(\hat{p}_{i j}^{s} \hat{h}_{i j}^{s}\right)$, where $n_{i j}^{s}$ is the number of hauled out seals in group $j$ of segment $i$; $\hat{p}_{i j}^{s}$ is the probability of detecting hauled-out seals within $900 \mathrm{~m}$ of the centre of the segment; and $\hat{h}_{i j}^{s}$ is the haulout probability at a specific time and day of the year.

Perpendicular sighting distances $(x)$ were truncated to the range $100-900 \mathrm{~m}$, and $\hat{p}_{i j}^{s}$ was estimated with the point independence method (Laake and Borchers, 2004), where detection probability for the observer team was $\hat{p}^{s}(x, y)=\hat{p}^{s}(0, \boldsymbol{y}) \hat{g}^{s}(x, \boldsymbol{y}) ; \boldsymbol{y}$ is a vector of sighting covariates; $\hat{p}^{s}(\mathbf{0}, \boldsymbol{y})$ is the detection probability at trackline assuming independent detection between observers; and $\hat{g}^{s}(x, \boldsymbol{y})$ is a multivariate detection function model (Marques and Buckland, 2003) of combined $x$ of the observer team, assuming $\hat{g}^{s}(0, \boldsymbol{y})=1$. We estimated $\hat{p}^{s}(0, \boldsymbol{y})$ with a logistic model with Bernoulli error using double observer mark-recapture data, and pooling across species. The detection probability function shape $\hat{g}^{s}(\boldsymbol{x}, \boldsymbol{y})$ assumed a multi-covariate half-normal model (Fig. 2; Supplementary material 1 ). We used package mrds of program $\mathrm{R}$ (2009), part of program Distance (Thomas et al., 2010), to estimate $\hat{p}^{s}(x, \boldsymbol{y})$.

We estimated $\hat{h}_{i j}^{s}$ using data for the survey period, pooling across regions, years and studies because of small sample size. When the tags transmitted, the time hauling out in each hour was expressed as a proportion. The $\hat{h}_{i}^{s}$ were then estimated with Generalized Additive Models (GAMs) with binomial error structure and logit-scale response (Southwell et al., 2008a,b) with haul out proportions as response and day of the year and time of the day as smoothed predictors. We used package $m g c v$ of program R, selecting thin plate regression splines with shrinkage as smoothers (Wood, 2006). The degree of smoothing was selected by minimum GCV/UBRE scores, controlling for over-fitting with a gamma multiplier of 1.4 .

The $\hat{n}_{i}^{s}$ were modelled with a generalized additive mixed model (GAMM) and spatially-explicit explanatory variables $(z)$ : latitude (lat) and longitude (lon) converted to west-east and south-north distances in $\mathrm{km}$, sea ice concentration (iceCon), distance to the sea ice edge (iceDist), distance to the shelf break (from pack-ice to closest $1000 \mathrm{~m}$ depth contour; shBreak), distance to nearest coast (coast), ocean depth (depth) and slope index (slope). Bathymetric data were from GEBCO 1-minute dataset (IOC et al., 2003). Two additional effects tested were species and the factor $E \_W$ which assumed different effects for the East and West of the Antarctic Peninsula.

The distribution of $\hat{n}_{i}^{s}$ was highly skewed by a high proportion of zeros and thus we considered a family of Tweedie distributions or a negative binomial distribution as possible error structures. The best distribution was selected through residual plot diagnostics (Supplementary material 1). The general model structure was

$E\left(n_{i}^{s}\right)=\left(\tau_{i}, l_{i} w\right) \exp \left[X_{i} \beta+\sum f_{k}\left(z_{i, k}\right)+Z_{i} b\right]+\epsilon_{i}$

where $\tau_{i}$ is segment sampling fraction, 1 or 2 , depending on sides of the aircraft observed; $l_{i}$ is segment length; $w$ is perpendicular distance right-truncation $(900 \mathrm{~m}) ; \beta$ is a fixed effects vector; $X_{i}$ is a fixed effects model matrix; $f_{k}\left(z_{i, k}\right)$ are one-dimensional smoothers of $k$ spatially referenced covariates; $Z$ is a random effects model matrix with $b \sim N\left(0, \psi^{\theta}\right)$; and residual error $\epsilon_{i}$, with $\epsilon_{i} \sim N(0, \Lambda)$ and covariance matrix $\Lambda$. Autocorrelation in residuals was modelled with autoregressive $\operatorname{AR}(q)$ and moving average $\mathrm{MA}(r)$ models (Pinheiro and Bates, 2000), as $\epsilon_{t}=\sum_{i=1}^{q} \phi_{i} \epsilon_{t-i}+\sum_{j=1}^{r} \varrho_{j} a_{t-j}+a_{t}$. Segments per survey day were considered sequentially at integer intervals, from $i=1$ to $t$. In the $i$ th segment, an $\operatorname{AR}(q)$ model assumed that $n_{i}^{s}$ was linearly related to up to $q$ previous segments,
OBSERVER 1

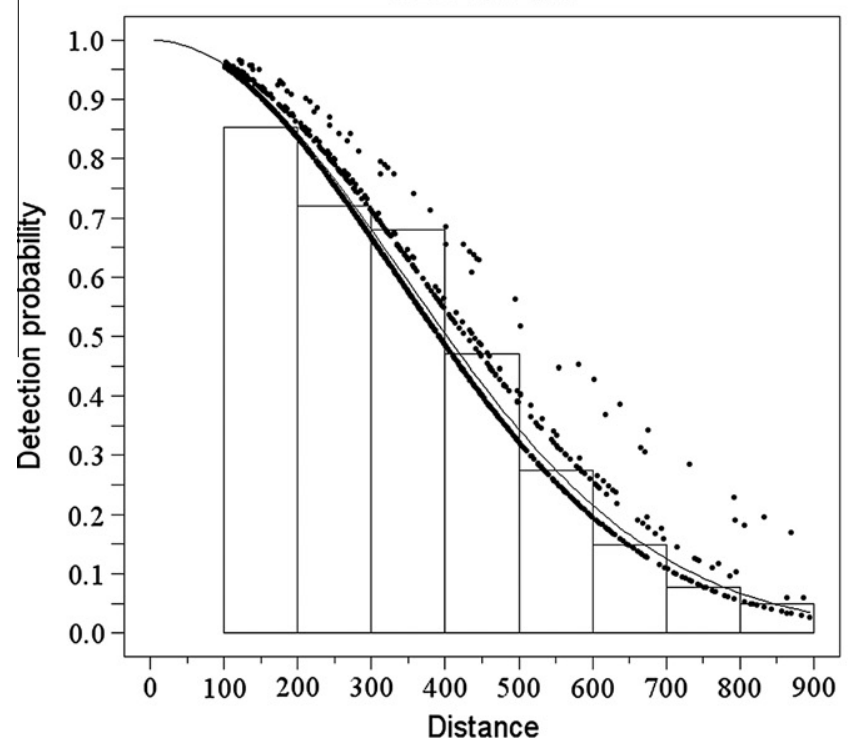

OBSERVER 2

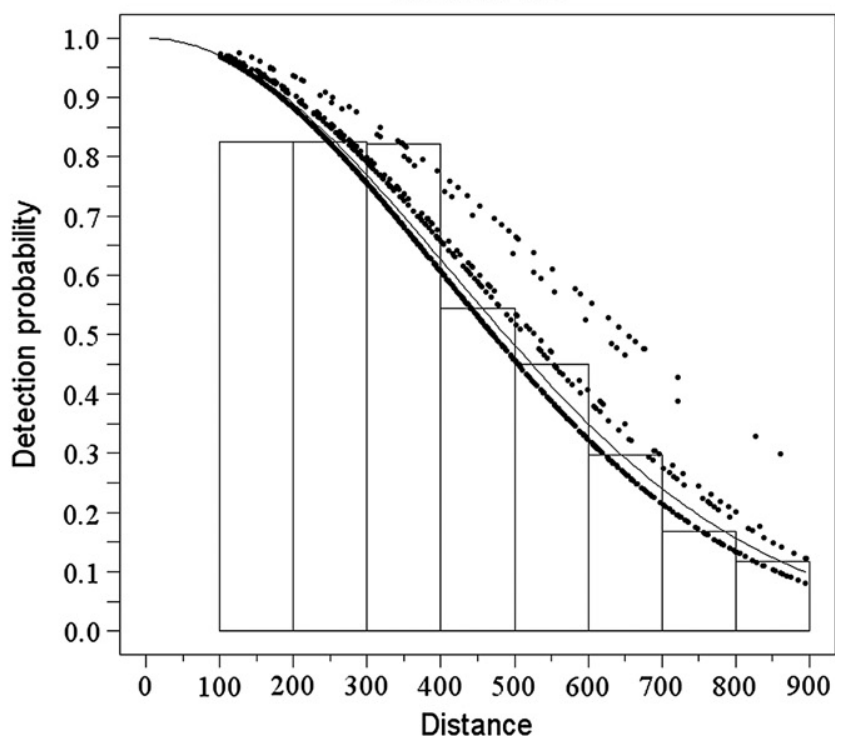

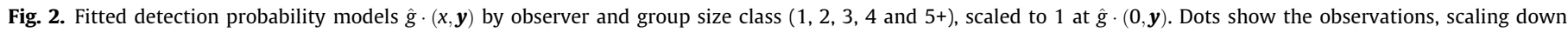
detectability with lower group size (size-biased detection), and the solid line shows an averaged estimate across group size class by observer. 
and a $\mathrm{MA}(r)$ model assumed that the $n_{i}^{s}$ more than $r$ segments apart were uncorrelated.

We used covariate correlation plots and PCA (Supplementary material 1) to examine spatial covariances, and explored GAMs excluding combinations of highly correlated covariates for competitive model structures. Covariates retained decreased the GCV score and increased the amount of deviance explained by $1-2 \%$ at least. Then, comparable GAMMs, selected with AIC, BIC and autocorrelation plots, were fitted to predict $E\left(\hat{n}_{i}^{s}\right)$, apportioning unidentified seals by segment $E\left(\hat{n}_{i}^{u s}\right)$ as $E\left(\hat{n}_{i}^{s}\right)^{*}=E\left(\hat{n}_{i}^{s}\right)+$ $E\left(\hat{n}_{i}^{u s}\right)\left[\frac{E\left(\hat{n}_{i}^{s}\right)}{\sum_{k=s} E\left(\hat{n}_{i}^{s}\right)}\right]$.

Abundance was obtained integrating a density surface predicted with the best GAMM over the pack-ice habitat for areas of interest: total pack-ice area (90-30 ${ }^{\circ} \mathrm{W}$ and $\left.60-80^{\circ} \mathrm{S}\right)$, WAP, WWS, MBA, FAO 48.1, and CCAMLR-SSMUs (Fig. 1).

We estimated variability with a nonparametric bootstrap. At each of 999 bootstraps, we combined: a sample with replacement of the entire haul-out records of each seal to obtain $\hat{h}_{i j}^{s}$; a moving blocks sample with replacement (Davison and Hinkley, 1997) of segments with double observer data to estimate $\hat{p}(0, \boldsymbol{y})$; and a moving blocks sample with replacement of all transects to estimate $\hat{p}^{s}(x, \boldsymbol{y})$ and derived parameters. Sampling blocks comprised five contiguous segments, approximately $25 \mathrm{~km}$ of effort, thus preserving the original autocorrelation within survey day. With each bootstrap a new GAMM was fitted to predict abundance, and confidence intervals were obtained with the percentile method.

\subsection{Suitable seal habitat analysis}

We used a presence-absence model corrected for detectability bias as response variable and environmental predictors to investigate suitable seal habitat. The $E\left(\hat{n}_{i}^{s}\right)$ were transformed into 1 and 0 for segments with and without seals. We used a GAM with a binomial error structure allowing for extra-binomial variation, and logit-scale response. Model selection followed the same procedure as above. The GAM predicted suitable pack-ice seal habitat based upon sea ice concentration and cover measured with the satellite record (1979-2011), and the habitat selection model of observed sea ice concentration and cover at the time of the survey as predictors of seal habitat. We bootstrapped the data as above to estimate variability. At each bootstrap replicate total suitable habitat was predicted for the time series, and simple linear and non-linear (GAM) regression models were fitted to investigate long term trends.

\subsection{Krill consumption by pack-ice seals}

Krill consumption over a year was modelled with a bioenergetic scheme for phocids (Worthy, 2001) modified as in Forcada et al. (2009) for crabeater, Weddell and leopard seals (Supplementary material 2). Daily ingested energy (Ie) depended on energy requirements $\left(e_{j}\right)$, and processing costs including digestive efficiency (de), urinary loss (ue), and heat increment of feeding ( $h i)$. This was expressed as $I e=\sum_{j} e_{j}\left[1-(1-d e)(1-u e)-I_{j} h i\right]^{-1}$, where energy requirements for growth $\left(e_{g}\right)$, reproduction $\left(e_{r}\right)$, resting at haulout $\left(e_{h}\right)$, diving $\left(e_{d}\right)$, and other activity $\left(e_{o}\right)$ depended on age, body mass $(\mathrm{bm})$ and sex. $I_{j}$ was an indicator variable with value 1 if requirement $r$ did not account for $h i$, and 0 otherwise.

Growth energy $e_{g}$ depended on the expected increment of $\mathrm{bm}$ at age, with age classes selected according to best available $b m$ at age data, which corresponded to ages $0-25,0-18$, and $0-12$ for crabeater, Weddell and leopard seals respectively; the highest classes aggregated ages from that value and above (Supplementary material 2). The interannual $\mathrm{bm}$ increment was used to estimate annual balance in total body gross energy (tbge; Reilly and Fedak, 1991), assuming isometric growth for lipid, protein, and total body water (tbw) increment.

An annual activity cycle for crabeater and Weddell seals with daily resolution was obtained combining available SDR/SRDL data, aggregating daily activity into times spent hauling out $(h)$, diving $(d)$, and cruising (o). A multinomial logit model estimated the daily proportion of time at each activity, with a factor with a level for each activity grouping multinomial observations. We fitted a Poisson GAM with log-scale response ( $h, d$ or $o$ ), and as predictors the activity factor and a smooth of day of the year by each factor level. The GAM predicted daily $h, d$ and $o$, which were scaled to sum to 1 . Variance was obtained by bootstrapping with replacement the entire records of instrumented seals. For leopard seals, tracking data were very limited and we combined published results in Kuhn et al. (2006) with SDR data from Southwell et al. (2008b) to provide an annually averaged estimate of $h$, the complement of which was time spent diving and cruising combined.

The $e_{r}$ in females included production of foetal tissue (pup at birth and placenta), predicted pregnancy energy increment using Brody's (1945) model for mammals, $18.48 \mathrm{bm}^{1.2}$, and lactation costs. Costs of activity were selected as multipliers of basal metabolic rate ( $\mathrm{bmr}$ ) from Kleiber's equation (1961), derived from data on Weddell seals (Castellini et al., 1992) (Supplementary material 2).

In what follows, scalars are in italics, in bold and lowercase are column vectors, and in bold and uppercase are matrices. Superscript $T$ stands for transpose and products are scalar except for matrix Hadamart product (o).

Annual energy requirements by age of females and males were

$\mathbf{e}_{F}=\left[\left(\mathbf{e}_{h} \mathbf{h}^{T}+\mathbf{e}_{d} \mathbf{d}^{T}+\mathbf{e}_{o} \mathbf{o}^{T}+\mathbf{f} \mathbf{e}_{r}+\mathbf{E}_{g}\right) \circ \mathbf{S}\right] \mathbf{I}$

and

$\mathbf{e}_{M}=\left[\left(\mathbf{e}_{h} \mathbf{h}^{T}+\mathbf{e}_{d} \mathbf{d}^{T}+\mathbf{e}_{o} \mathbf{o}^{T}+\mathbf{E}_{g}\right) \circ \mathbf{S}\right] \mathbf{I}$

where $\mathbf{e}_{h}, \mathbf{e}_{d}$, and $\mathbf{e}_{o}$ are age class vectors of costs of hauling out, diving and other activity; $\mathbf{h}, \mathbf{d}$, and $\mathbf{o}$ are vectors of daily predicted activity budgets; $\mathbf{f}$ is a vector of fertility at age; $\mathbf{e}_{r}$ is a vector of daily reproductive costs; $\mathbf{E}_{g}$ is a matrix of daily growth costs by age; $\mathbf{S}$ is a matrix of daily survival rate by age; and $\mathbf{I}$ is column vector of ones and size 365 , representing each day of the year.

Ingested energy $\mathbf{I} \mathbf{e}_{F}$ in females (similarly for males, $\mathbf{I e}_{M}$ ) was $\mathbf{I e}_{F}=\mathbf{e}_{F}[1-(1-d e)(1-u e)-h i]^{-1}$, where ue was 0.08 $(\mathrm{SD}=0.009)$ and $h i$ was $0.16(\mathrm{SE}=0.01)$ (Worthy, 2001), and krill de was $0.84(\mathrm{SE}=0.002)$ (Mårtensson et al., 1994). Per capita krill consumption for females $\left(\mathbf{k}_{F}\right)$ and males $\left(\mathbf{k}_{M}\right)$ at age was $\mathbf{k}_{F}=\mathbf{i e}_{F} \frac{k d}{k e}$. The proportion of krill in the diet $(k d)$ was selected as 0.95 ( $\mathrm{SE}=0.048)$ for crabeater seals, $0.01(\mathrm{SD}=0.001)$ for Weddell seals, and $0.40(S D=0.04)$ for leopard seals (Laws, 1984; Øristland, 1977; Siniff and Stone, 1985; BAS, unpublished). Mean krill energy (ke) was $3.7 \mathrm{MJ} \mathrm{kg}^{-1}(\mathrm{SE}=0.36)$ (Clarke, 1980).

Annual estimated krill consumption $(\widehat{k c})$ was $\left[s r \mathbf{k}_{F}+(1-s r) \mathbf{k}_{M}\right]$ $(\hat{n} \mathbf{w})$, where $s r$ is the sex ratio, assumed to be $0.5 ; \hat{n}$ is the abundance of seals; and $\mathbf{w}$ is the stable age structure vector scaled to sum 1 . We obtained $\mathbf{w}$ using survival and fecundity rates (Supplementary material 2) transformed into fertilities for a post-breeding census, in a matrix population model of equal dimensions as the maximum age class for each species. With it we obtained the stable age structure $(\mathbf{w})$ as the right eigenvector $\left(\mathbf{w}_{1}\right)$ associated to the dominant eigenvalue $\left(\lambda_{1}\right)$ (Caswell, 2001).

This Monte Carlo model produced krill consumption estimates for pack-ice seals in different areas, assuming that seal and krill stocks were geographically closed because there were no comprehensive data on seasonal movements of either group. In the MBA, however, we allowed for inter and intra-annual variation (2001- 
2002 ) in krill density. All estimates were obtained by combining the empirical results from the abundance and activity analyses with estimates of other parameters using 100,000 simulations (Supplementary material 2).

We generated log-normal krill density deviates by area according to published density estimates for the MBA (Lawson et al., 2008), and for the Scotia Sea and Antarctic Peninsula in 2000 (Fielding et al., 2011) at a spatial resolution of the coastal SSMUs in FAO Area 48.1. Krill densities were used to address seal demands with the uncertainty associated to these levels of resolution, and in comparison with standing stock estimates and reported catches (CCAMLR, 2011).

\section{Results}

\subsection{Pack-ice seal survey}

Total survey effort with optimum visibility was $2809 \mathrm{~km}$ of which 903 were in the WAP and 1906 in the WWS. It was organized in 561 segments, 178 in the WAP and 383 in the WWS. This corresponded to a prospected area of $24,658 \mathrm{~km}^{2}$, which was $2.1 \%$ of the total area, of which $7484 \mathrm{~km}^{2}$ was in the WAP (4.4\% of WAP) and $17174 \mathrm{~km}^{2}$ in the WWS (1.7\% of WWS). Total seal group sightings on effort were 2521, 1648 in WAP and 873 in WWS. The majority of the sightings were identified as crabeater seals (Table 1), with Ross seals only identified in one occasion.

\subsubsection{Detection probability}

Model selection of $\hat{p}(x, \boldsymbol{y})$ components is summarized in Supplementary material 1 . Species effects were discarded because leopard seals were only detected on 13 occasions, and unidentified seals were detected at distances of $200 \mathrm{~m}$ and beyond, precluding accurate and monotonically decreasing models. The transect with a double observer platform was $170.5 \mathrm{~km}$ long and produced 291 sightings, of which 213 were by the 1 st observer, 224 by the 2 nd and 146 by both. Models of $\hat{p}(0, \boldsymbol{y})$ retained observer effects, and the mean $\hat{p}_{1}(0)$ was estimated as 0.681 (95\% CI: $0.583-0.779$ ), the mean $\hat{p}_{2}(0)$ as $0.866(0.804-0.929)$, and a combined $\hat{p}(0)$ as 0.951 (0.941-0.956). The best model for $\hat{g}(x, \boldsymbol{y})$ included observer and group size effects, accounting for size-biased detection in both observers (Fig. 2). Observer 1 detected more groups than observer 2 (1323 vs. 1198), but observer 2 detected more groups of sizes 3 and above. Mean $\hat{\bar{g}}(x, \boldsymbol{y})$ was estimated as $0.400(0.384-0.416)$. Combining $\hat{p}(0)$ and $\hat{g}(x, \boldsymbol{y})$, mean $\hat{\bar{p}}(x, \boldsymbol{y})$ was $0.382(0.354-0.420)$. Bias corrected estimates of expected mean group size were obtained with these models (Table 1 ); the sizes of detected crabeater seal groups ranged from 1 to 17 , of Weddell seals from 1 to 10 , and all leopard seals were detected as individuals. Regional differences by species were non-significant.

Most of the survey was conducted between 11:00 and 17:00, which corresponded to a mean haul-out probability $(\bar{h})$ of 0.640

\section{Table 1}

Numbers of seal groups sighted, by species and region with estimated bias-corrected mean group size $E\left(\widehat{\overline{g s^{s}}}\right)$, and $95 \%$ bootstrap confidence intervals in parentheses.

\begin{tabular}{llll}
\hline & $\begin{array}{l}\text { West Antarctic } \\
\text { Peninsula }\end{array}$ & $\begin{array}{l}\text { Western } \\
\text { Weddell Sea }\end{array}$ & All regions \\
\hline Crabeater seal & 1338 & 612 & 1950 \\
& $1.71(1.55-1.89)$ & $1.52(1.33-1.75)$ & $1.65(1.51-1.79)$ \\
Weddell seal & 166 & 134 & 300 \\
& $1.36(1.10-1.69)$ & $1.21(1.06-1.39)$ & $1.29(1.13-1.48)$ \\
Leopard seal & 5 & 8 & 13 \\
Unidentified seal & 1 & 1 & 1 \\
& $1.21(1.10-1.37)$ & $1.12(1.06-1.19)$ & $1.17(1.10-1.26)$ \\
\hline
\end{tabular}

(0.409-0.872) for crabeater seals, $0.648(0.572-0.725)$ for Weddell seals, and $0.590(0.567-0.612)$ for leopard seals.

\subsubsection{Spatial models and pack-ice seal absolute density and abundance}

The wide latitudinal and narrow longitudinal configuration of the Antarctic Peninsula caused strong correlations between lat and lon, and between lat, lon and coast, depth and shBreak. The PCA (Supplementary material 1 ) produced a first component with location and topographic variables explaining $45 \%$ of the variance among segments, and a second (22\%) and a third (15\%) components with the highest correlations with sea ice variables. This supported a stratification of effort by sub-regions, with subsequent models of seal density including $E_{-} W$, shBreak, lat, lon and ice variables.

GAMs with a Tweedie error distribution and $\gamma=1.2$ provided the best fit, with most of the deviance explained by species and $E \_W$ (Supplementary material 1; Fig. S1.5 and Table S1.5). The best GAMs, with lowest GCV and AIC, included species, the interaction of species and $E_{-} W$ and either shBreak, or lon and lat. Both options explained approximately $68 \%$ of the deviance and had comparable AIC, but the non-uniform distribution of survey effort prevented the effective use of lat-lon two-dimensional smooths for prediction. Because lon had a highly variable smoother plot and effects comparable to $E_{-} W$ we retained models with shBreak instead.

The GAMMs included species, species:E_W and shBreak and additional effects were selected among uncorrelated variables. The best GAMM had a smooth of shBreak, a linear interaction of iceDist and $E_{-} W$, and an autoregressive residual structure of order 1 . This model had an adjusted $R^{2}$ of 0.498 (Tables S1.6 and S1.7, Supplementary material 1), and predicted density surfaces covering the study area for crabeater, Weddell and leopard seals (Fig. 3).

Absolute density and abundance estimates (Table 2) were much higher in the WAP than in the WWS for all species. Density was over nine times higher for crabeater seals, and approximately four times higher for the other species. Crabeater seals were highly abundant throughout the entire survey habitat and the highest density was found in the MBA. The abundance of leopard seals was very small throughout the entire area.

\subsection{Projected suitable habitat for pack-ice seals}

The best GAM included species and $E \_W$ as categorical variables and smooths of shBreak and iceCon as predictors. Based on this model, there were no appreciable trends in suitable seal habitat in the WWS. In contrast, there was significant directional loss in areas of the WAP (Fig. 4, Table 4) and especially in the MBA. There were also declines in FAO Area 48.1 for crabeater and Weddell seals, and in SSMUs 2, 5 and 6 for crabeater and leopard seals and in SSMU 8 for leopard seals. The pattern of suitable habitat loss was highly consistent with a decline in sea ice cover at the WAP, which was of 47\% (SD = 9) from 1979 to 2011, with an annual decline $1.4 \%$ ( $S D=0.3$ ). For the MBA, the long-term loss of sea ice cover was $66 \%(S D=12)$ and an annual decline of $2 \%(S D=0.4 \%)$. All SSMUs which showed long term declines were in the WAP.

\subsection{Seal energetics and krill consumption}

The maximum diving activity was during the winter months, when seals accumulate fat reserves after the moult and before the new pupping season. The maximum haul-out probabilities were between late spring and summer, during breeding and the subsequent moult. Daily activity probabilities for crabeater and Weddell seals over a year long period are shown in Fig. S2.2a and b of Supplementary material 2 . 

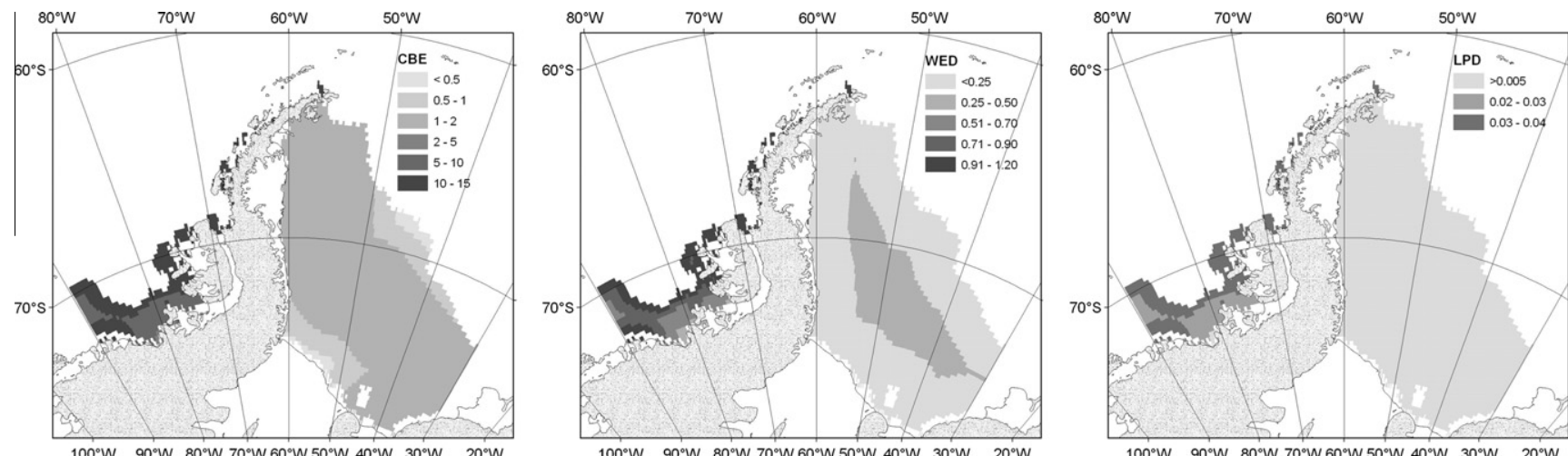

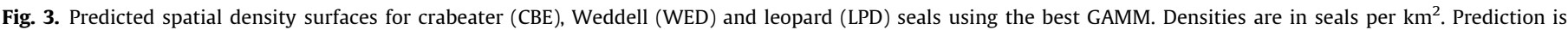
limited to the satellite sea ice habitat as defined by the bootstrap algorithm and within the limits of study area.

Table 2

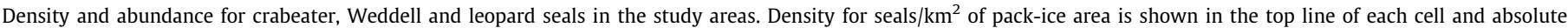

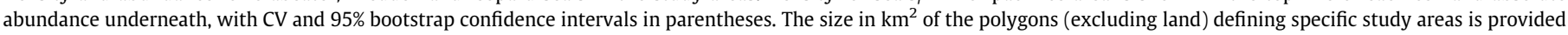

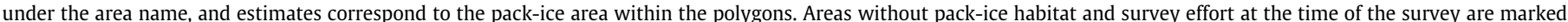
with symbol '-'.

\begin{tabular}{|c|c|c|c|}
\hline Region & Crabeater seal & Weddell seal & Leopard seal \\
\hline All & $\begin{array}{l}2.563(0.101 ; 2.132-3.120) \\
3,042,581(0.101 ; 2,530,617-3,703,918)\end{array}$ & $\begin{array}{l}0.311(0.193 ; 0.206-0.447) \\
369,174(0.193 ; 244,961-530,818)\end{array}$ & $\begin{array}{l}0.011(0.366 ; 0.005-0.022) \\
13,408(0.366 ; 5646-25,162)\end{array}$ \\
\hline WAP & $\begin{array}{l}10.984(0.156 ; 7.967-14.706) \\
1,858,201(0.156 ; 1,347,730-2,487,783)\end{array}$ & $\begin{array}{l}0.897(0.364 ; 0.387-1.650) \\
151,702(0.364 ; 65,515-279,028)\end{array}$ & $\begin{array}{l}0.031(0.408 ; 0.011-0.063) \\
5279(0.408 ; 1781-10,556)\end{array}$ \\
\hline WWS & $\begin{array}{l}1.163(0.133 ; 0.914-1.510) \\
1,184,380(0.133 ; 930,009-1,537,062)\end{array}$ & $\begin{array}{l}0.214(0.196 ; 0.142-0.303) \\
217,472(0.196 ; 144,832-309,279)\end{array}$ & $\begin{array}{l}0.008(0.555 ; 0.001-0.019) \\
8130(0.555 ; 1376-19,033)\end{array}$ \\
\hline $\begin{array}{l}\text { MBA } \\
249694\end{array}$ & $\begin{array}{l}13.837(0.228 ; 8.428-20.258) \\
373,132(0.228 ; 227,262-54,627)\end{array}$ & $\begin{array}{l}1.130(0.411 ; 0.442-2.251) \\
30,462(0.411 ; 11,915-60,702)\end{array}$ & $\begin{array}{l}0.039(0.441 ; 0.013-0.082) \\
1060(0.441 ; 348-2209)\end{array}$ \\
\hline $\begin{array}{l}\text { FAO } 48.1 \\
623974\end{array}$ & $\begin{array}{l}5.329(0.186 ; 3.641-7.452) \\
317,976(0.186 ; 217,263-444,622)\end{array}$ & $\begin{array}{l}0.514(0.304 ; 0.277-0.891) \\
30,657(0.304 ; 16,498-53,176)\end{array}$ & $\begin{array}{l}0.018(0.342 ; 0.008-0.033) \\
1089(0.342 ; 478-1980)\end{array}$ \\
\hline $\begin{array}{l}\text { SSMU1 } \\
422076\end{array}$ & $\begin{array}{l}1.416(0.129 ; 1.077-1.819) \\
14,429(0.129 ; 10,973-18,521)\end{array}$ & $\begin{array}{l}0.230(0.191 ; 0.153-0.325) \\
2344(0.191 ; 1554-3315)\end{array}$ & $\begin{array}{l}0.009(0.485 ; 0.002-0.018) \\
87(0.485 ; 23-185)\end{array}$ \\
\hline $\begin{array}{l}\text { SSMU2 } \\
35060\end{array}$ & $\begin{array}{l}14.391(0.282 ; 7.353-22.409) \\
39,123(0.282 ; 19,991-60,918)\end{array}$ & $\begin{array}{l}1.175(0.450 ; 0.404-2.470) \\
3194(0.450 ; 1099-6714)\end{array}$ & $\begin{array}{l}0.041(0.474 ; 0.012-0.088) \\
111(0.474 ; 33-239)\end{array}$ \\
\hline $\begin{array}{l}\text { SSMU3 } \\
15068\end{array}$ & - & - & - \\
\hline $\begin{array}{l}\text { SSMU4 } \\
15584\end{array}$ & - & - & - \\
\hline $\begin{array}{l}\text { SSMU5 } \\
21017\end{array}$ & $\begin{array}{l}1.130(0.174 ; 0.802-1.593) \\
1490(0.174 ; 1057-2101)\end{array}$ & $\begin{array}{l}0.208(0.227 ; 0.132-0.304) \\
274(0.227 ; 174-400)\end{array}$ & $\begin{array}{l}0.008(0.560 ; 0.001-0.018) \\
10(0.560 ; 2-24)\end{array}$ \\
\hline $\begin{array}{l}\text { SSMU6 } \\
27447\end{array}$ & $\begin{array}{l}14.287(0.310 ; 6.512-22.650) \\
29,017(0.310 ; 13,225-46,001)\end{array}$ & $\begin{array}{l}1.166(0.471 ; 0.376-2.477) \\
2369(0.471 ; 764-5031)\end{array}$ & $\begin{array}{l}0.041(0.493 ; 0.011-0.090) \\
82(0.493 ; 22-182)\end{array}$ \\
\hline $\begin{array}{l}\text { SSMU7 } \\
35322\end{array}$ & - & - & - \\
\hline $\begin{array}{l}\text { SSMU8 } \\
58704\end{array}$ & $\begin{array}{l}1.211(0.205 ; 0.857-1.812) \\
52,265(0.205 ; 36,986-78,198)\end{array}$ & $\begin{array}{l}1.166(0.273 ; 0.376-2.477) \\
9267(0.273 ; 5697-15,024)\end{array}$ & $\begin{array}{l}0.008(0.592 ; 0.002-0.020) \\
346(0.592 ; 67-848)\end{array}$ \\
\hline
\end{tabular}

Limited data for leopard seals only allowed for minimum estimates of survival which were $0.51(\mathrm{SD}=0.08), 0.74(0.14)$, and $0.84(0.10)$ for pups, juveniles and adults respectively. In comparison, mean adult survival for crabeater seals was $0.93(0.05)$ and $0.90(0.04)$ for Weddell seals. Estimates of life history rates at age for each species are shown in Fig. S2.3a-c, Supplementary material 2.

The best model options and parameter estimates for body mass at age by sex are in Fig. S2.3a-c, Supplementary material 2. The estimated population mean $\mathrm{bm}$, weighted by population structure, was: 175.2 (3.2) and 170.8 (5.6) kg for female and male crabeater seals; 231.7 (10.5) and 223.6 (8.8) kg for Weddell seals; and 300.8 (14.3) and 251.1 (11.3) kg for leopard seals. Note that mean values for adult individuals are higher than these averages for all species.

Daily mean energy and krill requirements were 34.2 (2.5) and 30.1 (2.4) $\mathrm{MJ} \mathrm{day}^{-1}$, and 12 (1.8) and 10.5 (1.6) kg of krill for female and male crabeater seals respectively; 39.3 (2.6) and 33.1 (2.3) $\mathrm{MJ} \mathrm{day}^{-1}$, and $0.145(0.025)$ and $0.122(0.021) \mathrm{kg}$ of krill for female and male Weddell seals; and 43.2 (3.4) and 35.8 (2.9) $\mathrm{MJ} \mathrm{day}^{-1}$, and 6.4 (1.1) and $5.3(0.9) \mathrm{kg}$ of krill for female and male leopard seals; daily krill demands are corrected by the proportion of krill in the diet and weighted by age structure. Mean parameter values by sex and age for each species are shown in Fig. S2.3a-c, Supplementary material 2. The estimated total tons of krill consumed by area are in Table 3 . 


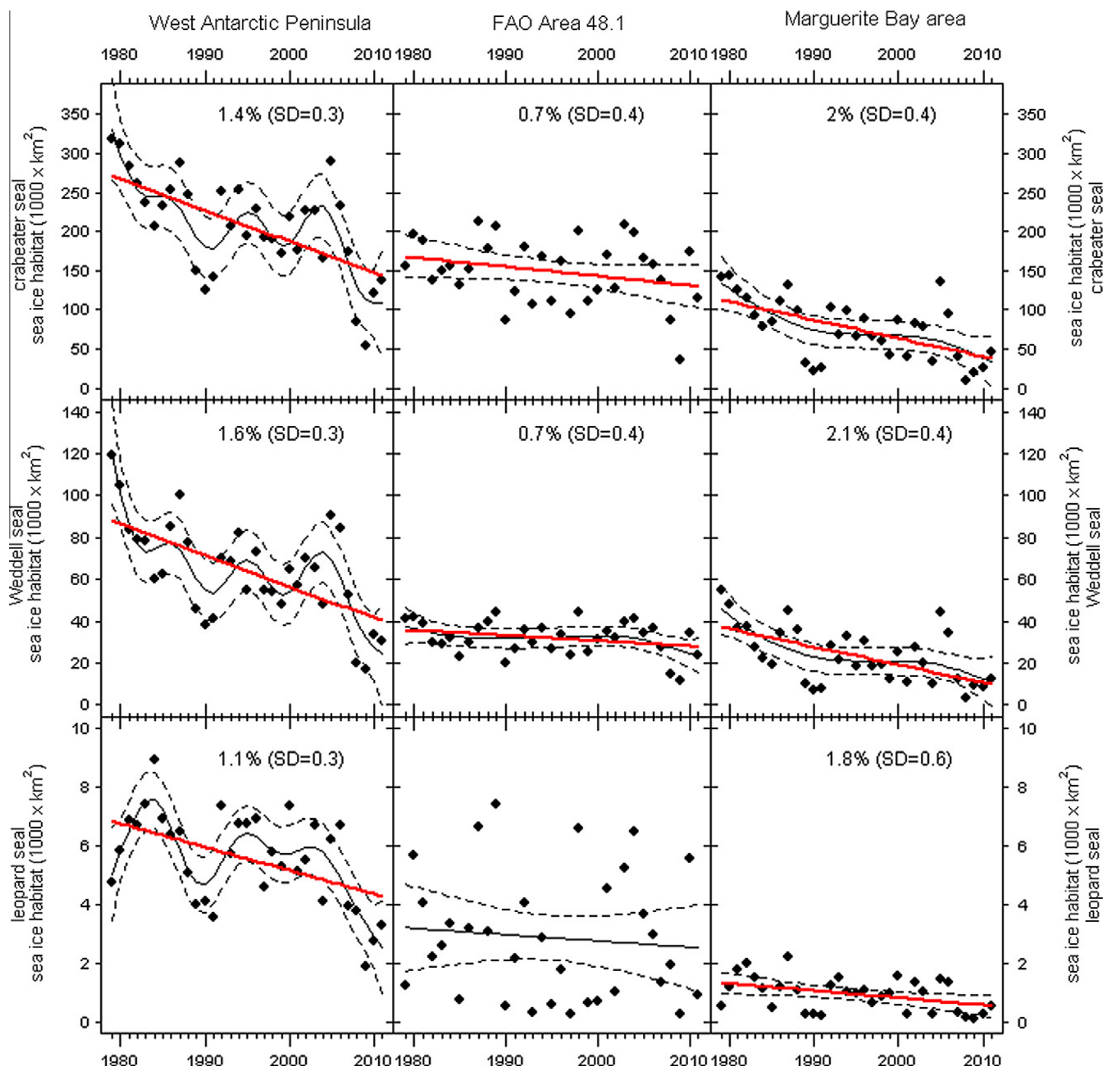

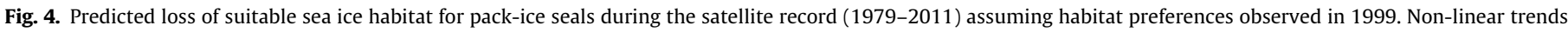

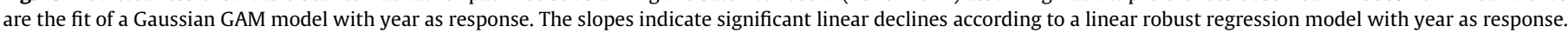

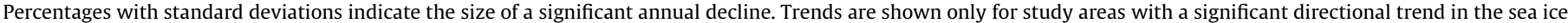
environment. Results for SSMUs are in Table 4.

\subsection{Krill consumption by seals in relation with availability, fishing and suitable habitat}

The highest krill consumption by seals in FAO area 48.1 corresponded to the MBA. Further north in the SSMUs, krill consumption was low compared with the krill available, and was insignificant for Weddell and leopard seals. The fishery impact was smaller than the impact of crabeater seals. In all the coastal SSMUs of the WAP however the sea-ice environment and suitable seal habitat declined significantly over time for at least one species, while krill catches increased since 2000 . Regional results are summarised in Table 4.

The MBA had the highest density of seals and also the highest percentage of available krill consumed (Table 5), but there was no krill fishing reported; the average krill demand was high for crabeater seals and insignificant for the other species. Inter and intra-annual krill biomass variation was very high, and if the density of seals were constant over an annual period, the krill biomass available in the winter of 2001 would not have sustained the observed crabeater seal population (Table 5).

\section{Discussion}

We present the first line transect-based density estimates for pack-ice seals in the WAP and WWS that account for detectability and availability bias and uncertainty in spatial prediction. Similar estimates for East Antarctica (Southern Indian Ocean; Southwell et al., 2008a,b) and the Amundsen-Ross Sea area (South Pacific; Bengtson et al., 2011) indicate densities for crabeater seals comparable to those of the WWS. At the WAP, crabeater seal density was much higher than elsewhere, and Weddell seal density was higher 
Table 3

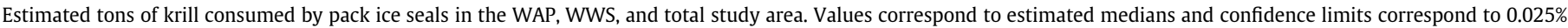
and $0.975 \%$ percentiles.

\begin{tabular}{|c|c|c|c|}
\hline & West Antarctic Peninsula & Western Weddell Sea & All regions \\
\hline Crabeater seal & $7,477,794(4,889-11,482,293)$ & $4,782,779(3,226,201-7,119,412)$ & $12,262,550(8,118,436-18,606,344)$ \\
\hline Weddell seal & $6901(3295-14,432)$ & $10,339(6540-16,386)$ & $17,261(9892-30,725)$ \\
\hline Leopard seal & $10,348(4593-23,437)$ & $15,071(5287-42,942)$ & $25,429(9879-66,250)$ \\
\hline All seals & $7,495,686(4,900,083-11,516,539)$ & $4,809,011(3,243,056-7,166,338)$ & $12,306,618(8,141,831-18,682,074)$ \\
\hline
\end{tabular}

Table 4

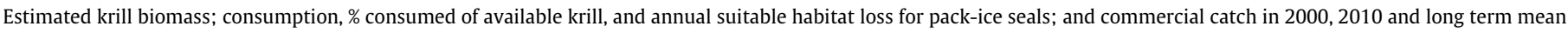

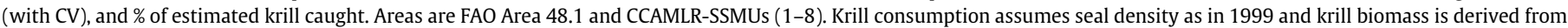

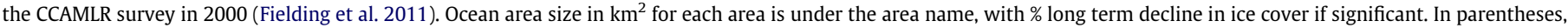
$95 \%$ confidence limits or SD, as indicated. NS is non-significant.

\begin{tabular}{|c|c|c|c|c|c|c|c|c|}
\hline & \multirow{2}{*}{$\begin{array}{l}\text { Krill biomass } \\
(\times 1000 \text { Tonnes })\end{array}$} & \multicolumn{4}{|c|}{ Krill consumption ( $\times 1000$ tonnes) and suitable habitat loss } & \multicolumn{3}{|c|}{ Krill fishery ( $\times 1000$ tonnes; $\%$ of stock) } \\
\hline & & Crabeater seal & Weddell seal & Leopard seal & All species & 2000 & 2010 & Mean \\
\hline $\begin{array}{l}\text { FAO } 48.1 \\
624228 \\
-23(14) \%\end{array}$ & $36,698(26,592-50,985)$ & $\begin{array}{l}1274(797,2043) \\
3.4(2.0,6.2) \% \\
-0.7(\mathrm{SD}=0.4) \%\end{array}$ & $\begin{array}{l}1.4(0.8,2.7) \\
<0.01 \% \\
-0.7(\mathrm{SD}=0.4) \%\end{array}$ & $\begin{array}{l}2.2(1.1,4.4) \\
<0.01 \% \\
\text { NA }\end{array}$ & $\begin{array}{l}1277(799,2048) \\
3.4(2.0,6.2) \%\end{array}$ & $\begin{array}{l}72 \\
0.20(0.14,0.28)\end{array}$ & $\begin{array}{l}153 \\
0.42(0.30,0.59)\end{array}$ & $\begin{array}{l}50(C V=0.68) \\
0.14(0.10,0.19)\end{array}$ \\
\hline $\begin{array}{l}\text { All SSMUs } \\
592288\end{array}$ & $36,076(25,971-50,343)$ & $\begin{array}{l}540(312,944) \\
1.5(0.8,2.9) \% \\
\text { NS }\end{array}$ & $\begin{array}{l}0.8(0.4,1.6) \\
<0.01 \% \\
\text { NS }\end{array}$ & $\begin{array}{l}1.2(0.4,3.3) \\
<0.01 \% \\
\text { NS }\end{array}$ & $\begin{array}{l}542(313,948) \\
1.5(0.8,2.9) \%\end{array}$ & $\begin{array}{l}72 \\
0.20(0.14,0.28)\end{array}$ & $\begin{array}{l}153 \\
0.42(0.30,0.59)\end{array}$ & $\begin{array}{l}50(\mathrm{CV}=0.68) \\
0.14(0.10,0.19)\end{array}$ \\
\hline $\begin{array}{l}\text { SSMU1 } \\
377054\end{array}$ & $7032(3821-12,918)$ & $\begin{array}{l}58(39,86) \\
0.8(0.4,1.7) \% \\
\text { NS }\end{array}$ & $\begin{array}{l}0.1(0.07,0.18) \\
<0.01 \% \\
\text { NS }\end{array}$ & $\begin{array}{l}0.16(0.07,0.42) \\
<0.01 \% \\
\text { NS }\end{array}$ & $\begin{array}{l}59(40,87) \\
0.8(0.4,1.7) \%\end{array}$ & $\begin{array}{l}1.3 \\
0.02(0.01,0.04)\end{array}$ & $\begin{array}{l}0.07 \\
<0.01\end{array}$ & $\begin{array}{l}3.2(C V=1.53) \\
0.05(0.02,0.08)\end{array}$ \\
\hline $\begin{array}{l}\text { SSMU2 } \\
37627 \\
-28(8) \%\end{array}$ & $5046(3681-6912)$ & $\begin{array}{l}153(83,286) \\
3.0(1.5,6.1) \% \\
-0.8(\mathrm{SD}=0.3) \%\end{array}$ & $\begin{array}{l}0.1(0.06,0.34) \\
<0.01 \% \\
\text { NS }\end{array}$ & $\begin{array}{l}0.21(0.09,0.53) \\
<0.01 \% \\
-0.8(\mathrm{SD}=0.3) \%\end{array}$ & $\begin{array}{l}154(83,287) \\
3.0(1.5,6.1) \%\end{array}$ & $\begin{array}{l}0.1 \\
<0.01\end{array}$ & $\begin{array}{l}6.0 \\
0.08(0.05,0.16)\end{array}$ & $\begin{array}{l}0.7(C V=2.10) \\
0.01(0.01,0.02)\end{array}$ \\
\hline $\begin{array}{l}\text { SSMU3 } \\
15778\end{array}$ & $2116(1544-2898)$ & $\begin{array}{l}- \\
- \\
\text { NS }\end{array}$ & $\begin{array}{l}- \\
- \\
\text { NS }\end{array}$ & $\begin{array}{l}- \\
- \\
\text { NS }\end{array}$ & - & $\begin{array}{l}31 \\
1.46(1.06,2)\end{array}$ & $\begin{array}{l}17 \\
0.25(0.13,0.45)\end{array}$ & $\begin{array}{l}19(\mathrm{CV}=0.81) \\
0.90(0.66,1.24)\end{array}$ \\
\hline $\begin{array}{l}\text { SSMU4 } \\
16384\end{array}$ & $2197(1603-3010)$ & $\begin{array}{l}- \\
- \\
\text { NS }\end{array}$ & $\begin{array}{l}- \\
- \\
\text { NS }\end{array}$ & $\begin{array}{l}- \\
\text { NS }\end{array}$ & - & $\begin{array}{l}20 \\
0.91(0.66,1.25)\end{array}$ & $\begin{array}{l}4.8 \\
0.07(0.04,0.12)\end{array}$ & $\begin{array}{l}8.5(\mathrm{CV}=0.96) \\
0.39(0.28,0.53)\end{array}$ \\
\hline $\begin{array}{l}\text { SSMU5 } \\
22255 \\
-26(11) \%\end{array}$ & $2984(2177-4088)$ & $\begin{array}{l}6.0(3.8,9.4) \\
0.2(0.1,0.3) \% \\
-0.8(\mathrm{SD}=0.3) \%\end{array}$ & $\begin{array}{l}0.01(0.008,0.02) \\
<0.01 \% \\
\text { NS }\end{array}$ & $\begin{array}{l}0.02(0.1,0.05) \\
<0.01 \% \\
-0.8(\mathrm{SD}=0.3) \%\end{array}$ & $\begin{array}{l}6.0(3.8,9.5) \\
0.2(0.1,0.3) \%\end{array}$ & $\begin{array}{l}6.1 \\
0.21(0.15,0.28)\end{array}$ & $\begin{array}{l}86 \\
1.22(0.66,2.24)\end{array}$ & $\begin{array}{l}3.9(\mathrm{CV}=4.00) \\
0.13(0.10,0.18)\end{array}$ \\
\hline $\begin{array}{l}\text { SSMU6 } \\
28677 \\
-21(13) \%\end{array}$ & $3847(2805-5268)$ & $\begin{array}{l}113(58,221) \\
2.9(1.4,6.2) \% \\
-0.7(S D=0.4) \%\end{array}$ & $\begin{array}{l}0.1(0.04,0.26) \\
<0.01 \% \\
\text { NS }\end{array}$ & $\begin{array}{l}0.16(0.06,0.41) \\
<0.01 \% \\
-1.7(\mathrm{SD}=0.9) \%\end{array}$ & $\begin{array}{l}113(58,221) \\
2.9(1.4,6.2) \%\end{array}$ & $\begin{array}{l}2.9 \\
0.08(0.06,0.10)\end{array}$ & $\begin{array}{l}38 \\
0.54(0.29,0.99)\end{array}$ & $\begin{array}{l}3(\mathrm{CV}=2.80) \\
0.08(0.06,0.11)\end{array}$ \\
\hline $\begin{array}{l}\text { SSMU7 } \\
36369\end{array}$ & $4877(3558-6681)$ & $\begin{array}{l}- \\
- \\
\text { NS }\end{array}$ & $\begin{array}{l}- \\
- \\
\text { NS }\end{array}$ & $\begin{array}{l}- \\
- \\
\text { NS }\end{array}$ & - & $\begin{array}{l}11 \\
0.22(0.16,0.30)\end{array}$ & $\begin{array}{l}1.8 \\
0.03(0.01,0.05)\end{array}$ & $\begin{array}{l}12(C V=1.11) \\
0.24(0.17,0.33)\end{array}$ \\
\hline $\begin{array}{l}\text { SSMU8 } \\
58145\end{array}$ & $7797(5688-10,681)$ & $\begin{array}{l}209(127,344) \\
2.7(1.5,4.8) \% \\
\text { NS }\end{array}$ & $\begin{array}{l}0.4(0.2,0.8) \\
<0.01 \\
\text { NS }\end{array}$ & $\begin{array}{l}0.6(0.2,1.9) \\
<0.01 \\
-2.2(\mathrm{SD}=0.7) \%\end{array}$ & $\begin{array}{l}210(127,346) \\
2.7(1.5,4.8) \%\end{array}$ & - & - & $\begin{array}{l}0.1(\mathrm{CV}=5.43) \\
<0.01\end{array}$ \\
\hline
\end{tabular}

Table 5

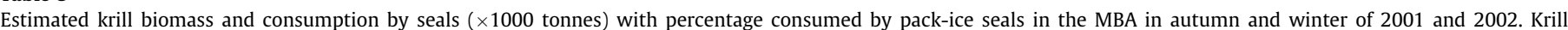

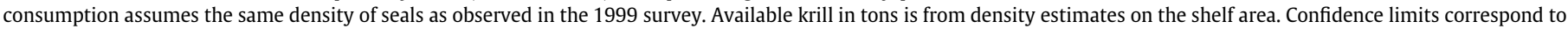
$0.025 \%$ and $0.975 \%$ percentiles.

\begin{tabular}{|c|c|c|c|c|c|}
\hline & Autumn 2001 & Winter 2001 & Autumn 2002 & Winter 2002 & Average \\
\hline Krill biomass ( $\times 1000$ tonnes $)$ & $9722(3478-28,366)$ & $168(66-468)$ & $4852(2525-9651)$ & $7459(2304-26,150)$ & $6011(3268-12,341)$ \\
\hline \multicolumn{6}{|l|}{ Consumption } \\
\hline Crabeater 1483 (871-2532) & $15(5-48) \%$ & $879(280-2586) \%$ & $30(13-71) \%$ & $20(5-72) \%$ & $25(10-56) \%$ \\
\hline Weddell $1.36(0.60-3.08)$ & $<0.1 \%$ & $0.8(0.2-2.8) \%$ & $<0.1 \%$ & $<0.1 \%$ & $<0.1 \%$ \\
\hline Leopard 2.05 (0.86-4.90) & $<0.1 \%$ & $1.2(0.3-4.4) \%$ & $<0.1 \%$ & $<0.1 \%$ & $<0.1 \%$ \\
\hline All seals 1487 (873-2539) & $15(5-48) \%$ & $881(280-2592) \%$ & $31(13-71) \%$ & $20(5-72) \%$ & $25(10-56) \%$ \\
\hline
\end{tabular}

than in the Amundsen-Ross Sea. Leopard seal density in the WAP was comparable to densities elsewhere, but at the WWS was much lower, which could reflect either the species' rarity or the low number of observations produced, as occurred in surveys of East Antarc- tica (Southwell et al., 2008b). Finally, our survey failed to produce estimates for Ross seals, and this could be explained by the dates of the survey, when haul-out probabilities were small (Southwell et al., 2008c) and most seals could be absent from the survey area. 
Erickson and Hanson (1990) provided density estimates for the Amundsen-Bellingshausen Seas and the WWS from the early 1970 s to early 1980 s that were 2.3 and 19 times higher than our estimates for crabeater seals in overlapping areas, and similarly higher for Weddell and leopards seals. They also reported a lower density for Ross seals than for leopard seals, but much higher than in our survey. Due to fundamental methodological differences between their estimates and ours, population trends in the region should be considered with caution. To date, only a long term study at Anvers Island indicates a verifiable decline for a single Weddell seal colony (Siniff et al., 2008), and there is a need to investigate population trends for all species at a wider scale to understand change.

Our analysis of suitable habitat indeed suggests long-term declines in the WAP which could entail directional changes in distribution and density of pack-ice seals. Such changes for instance have been observed in emperor penguins (Trathan et al., 2011), which are an ice obligate species. Our models made strong assumptions about habitat preferences, and seal habitat projections closely tracked the evident decline of pack-ice at the WAP (Parkinson, 2004; Stammerjohn et al., 2008; Costa et al., 2010; Dinniman et al., 2011). However, it is not clear whether and how the pack-ice habitat is critical to the seals in the absence of an alternative substrate, and understanding the dependence of seals on the pack-ice is important to evaluate how much ice loss is required before seal population declines are likely to occur.

Another important result is that the highest loss of apparently suitable habitat would have occurred at the MBA where pack-ice seals are expected to be abundant. The MBA is warming rapidly (Meredith and King, 2005; Vaughan et al., 2003) and shows profound biological changes resulting from sea ice loss (Clarke et al., 2007; Ducklow et al., 2007). Changes include possible declines, and increasing interannual variation in krill biomass (Atkinson et al., 2004). A recent habitat analysis for crabeater seals (Friedlander et al., 2011) confirms that their distribution in the MBA is not so much determined by proximity to krill but by sea-ice cover and the preference for shallow coastal areas (Burns et al., 2004, 2008; Costa et al., 2010). In addition, our analysis indicates that crabeater seals were more abundant where sea ice concentration was high, and where the pack-ice was closer to the shelf break. This suggests that sea-ice contraction could potentially modify the density of seals and the krill and the access of seals to the krill, but if it is the case, the mechanisms underlying these processes remain unclear.

Given its abundance, the crabeater seal is probably the major krill consumer of the Antarctic Peninsula-Scotia Sea-Weddell Sea region. Assuming 95\% of krill in the diet, total consumption would compare to approximately $20 \%$ of the standing stock estimate for the Scotia Sea including the northwestern Antarctic Peninsula (Fielding et al., 2011), roughly $17 \%$ of the krill stock in the extended survey area. This places the crabeater seal as the top krill consumer, even above whales (Reilly et al., 2004), Antarctic fur seals (Boyd, 2002) and other predators (Hill et al., 2007). This also highlights the extreme dependence of crabeater seals on krill, if there are no alternative food sources as it has been suggested (Ducklow et al., 2007; Murphy et al. 2007), which could influence crabeater seal density, as occurs in other predators (e.g. Trivelpece et al., 2011), if krill biomass is declining. The availability of alternative prey components thus needs further research.

\subsection{Caveats and uncertainty}

Although this analysis aimed at generating the highest level of certainty in estimating population and krill consumption parameters for pack-ice seals given the available data, there are a number of important caveats. First, both the krill and seal population assessments are now over 10 years old, and constitute only a snapshot in time for a region demographically open for krill and seals. Second, despite the similarity of our estimates in mean daily krill requirements with independent estimates (Naumov and Chekunova, 1980; Laws 1984), our estimates were limited by incomplete and nonconcurrent biometric, life history, diet composition and other data, which had to be pooled across regions, studies and species. This is problematic because food consumption estimates are sensitive to population density (e.g. Boyd, 2002) and diet composition (e.g. Forcada et al., 2009), which may vary considerably over space and time. Third, the spatial resolution of the consumption estimates assumed a static stock of seals and krill. Crabeater seals are mobile even if constrained to remain close to the pack-ice (Burns et al., 2004, 2008; Costa et al., 2010), and they move across small-scale areas in search for food, particularly given the dynamics of sea ice and krill; krill is also highly dynamic in space and time (Murphy et al., 2007; Lawson et al., 2008). Fourth, the limited spatial resolution of the aerial survey across the fishery area, and the habitat-based modelling to obtain the best possible seal density estimates, affected extrapolation of density to SSMUs, especially in those with little or no pack-ice. Despite the absence of sea-ice, these areas still constitute an important source of krill advected by the Antarctic Circumpolar Current that post-moulting seals are likely exploit. In areas of more intensive fishing, such as in SSMUs 5 and 6, it is thus not clear what fraction of the total available krill biomass is vulnerable to pack-ice seals. Finally, seals eat much more krill than is taken by the fishery, and taken together they represent approximately between $11 \%$ and $26 \%$ of the standing stock. Nevertheless, there is considerable uncertainty about the biomass of krill in the area (Lawson et al., 2008; Nicol et al., 2011) and at a much larger scale (Atkinson et al., 2009), which will greatly influence estimates of krill consumption and fishing impacts in relation to standing stock.

All these caveats indicate a very high level of uncertainty, which should reflect in the level of precaution in the management of the krill fishery in order to take the ecological needs of Antarctic packice seals into account.

\subsection{Management implications}

One of the CCAMLR management objectives for the Southern Ocean krill fishery is the "maintenance of the ecological relationships between harvested, dependent and related populations of Antarctic marine resources and the restoration of depleted populations to predefined levels". CCAMLR considers the implementation of its ecosystem approach to management through operational conservation objectives of krill predators (Constable, 2011), which require the assessment of the status of target species and their dependent predators in order to design management strategies. However, in spite of all our efforts, we still know very little about krill-pack-ice seal-environment dynamics in relation to the fishery.

Antarctic pack-ice seals are numerically important in the West Antarctic Peninsula, where a considerable part of the fishing operation takes place. Seal densities here are probably much higher than elsewhere in the Southern Ocean, and the crabeater seal demands for krill may comprise up to $15 \%$ or more of the standing stock.

Pack-ice seals as a group and especially crabeater seals are probably sensitive to the loss of sea ice (Siniff et al., 2008; Costa et al., 2010) to some degree, and sea ice contraction is probably reducing their habitat, resulting in a stress on some populations. Currently, their apparent preferred habitat is contracting faster where the krill biomass is likely to be in decline and fishing has increased and is more intensive.

Increasing fishing in the region is thus likely to add stress to the already stressed krill-seal dynamics. In particular, expanding the 
fishing operation to the MBA which is currently not fished for krill, because is a potentially critical source of krill for the Antarctic Peninsula and the Scotia Sea, including SSMUs, but also where environmental change is more significant.

Conserving marine resources requires understanding how compounded pressures affect populations and communities. Inter alia, the effects of fisheries with climate and environmental change (Delord et al., 2008; Rolland et al., 2009; Trebilco et al., 2011), and with management decisions (e.g. Okes et al., 2009; Pichegru et al., in press). The management of the krill fishery should thus carefully consider the large uncertainty associated with the data presented here, which calls for a precautionary approach rather than management based on specific conservation objectives for Antarctic pack-ice seals.

\section{Acknowledgments}

We thank a large number of people who participated or assisted in the preparation and development of the survey and data collation. We thank Dr. Lesley Thompson and the pilots of the British Antarctic Survey (BAS) air unit for their work. The Natural Environment Research Council funded the survey, and this analysis was funded as part of the BAS core science programme. Crabeater seal instrumentation was carried out under permits of the Commonwealth of Australia Antarctic Seals Conservation Regulations and was approved by the Antarctic Animal Ethics Committee. Leopard seal handling was authorized and endorsed by the Australian Antarctic Science Animal Care and Ethics Committee No. 1144. This work was partly supported by the US National Science Foundation under Grant OPP-9815961, and additional work in the Antarctic Peninsula was supported by the National Science Foundation under Grants ANT-0440687, ANT-0840375, ANT-0838937, and ANT-0440687. This manuscript is contribution No. 716 to the US GLOBEC programme.

\section{Appendix A. Supplementary material}

Supplementary data associated with this article can be found, in the online version, at doi:10.1016/j.biocon.2012.02.002.

\section{References}

Anonymous, 1995. Antarctic Pack Ice Seals: An international research program coordinated by the SCAR Group of Specialists on Seals. Unpublished Report of the 1995 APIS Program Planning Meeting, National Marine Mammal Laboratory, Alaska Fisheries Science Center, Seattle, USA, pp. 1-26.

Atkinson, A.A., Siegel, V., Pakhomov, E.A., Rothery, P., 2004. Long-term decline in krill stock and increase in salps within the Southern Ocean. Nature 432, 100 103.

Atkinson, A.A., Siegel, V., Pakhomov, E.A., Jessopp, M.J., Loeb, V., 2009. A re-appraisal of the total biomass and annual production of Antarctic krill. Deep-Sea Res. Part I 56, 727-740.

Bengtson, J.L., Laake, J.L., Boveng, P.L., Cameron, M.F., Hanson, B., Stewart, B., 2011. Distribution, density, and abundance of pack-ice seals in the Amundsen and Ross Seas. Antarctica. Deep-Sea Res. Part II 58, 1261-1276.

Boyd, I.L., 2002. Estimating food consumption of marine predators: Antarctic fur seals and macaroni penguins. J. Appl. Ecol. 39, 103-119.

Brody, S., 1945. Bioenergetics and Growth with Special Reference to the Efficiency Complex in Domestic Animals. Hafner Publishing Company Inc., New York.

Burns, J.M., Costa, D.P., Fedak, M.A., Hindell, M.A., Bradshaw, C.J.A., Gales, N.J. McDonald, B., Trumble, S.J., Crocker, D.E., 2004. Winter habitat use and foraging behavior of crabeater seals along the Western Antarctic Peninsula. Deep-Sea Res. Part. II 51, 2279-2303.

Burns, J.M., Hindell, M.A., Bradshaw, C.J.A., Costa, D.P., 2008. Fine-scale habitat selection of crabeater seals as determined by diving behavior. Deep-Sea Res. Part. II 55, 500-514.

Castellini, M.A., Kooyman, G.L., Ponganis, P.J., 1992. Metabolic rates of freely diving Weddell seals: correlations with oxygen stores, swim velocity and diving duration. J. Exp. Biol. 165, 181-194.

Caswell, H., 2001. Matrix Population Models: Construction, Analysis and Interpretation, second ed. Sinauer Associates, Sunderland, Massachusetts.

CCAMLR, 2008. Report of the Twenty-Seventh Meeting of the Scientific Committee Report. SC-CAMLR-XXVII/Annex 4, Hobart, Australia. <http://www.ccamlr.org>.
CCAMLR (Secretariat), 2011. Krill Fishery Report: 2011 Update. Document WGEMM-11/5. CCAMLR, Hobart, Australia. <http://www.ccamlr.org/>.

Clarke, A., 1980. The biochemical composition of krill, Euphausia superba Dana, from South Georgia. J. Exp. Mar. Biol. Ecol. 43, 221-236.

Clarke, A., Murphy, E.J., Meredith, M.P., King, J.C., Peck, L.S., Barnes, D.K.A., Smith, R.C., 2007. Climate change and the marine ecosystem of the western Antarctic Peninsula. Philos. Trans. Roy. Soc. B 362, 149-166.

Comiso, J., 1999 (updated 2008). Bootstrap Sea Ice Concentrations from NIMBUS-7 SMMR and DMSP SSM/I. National Snow and Ice Data Center. Digital Media. Boulder, Colorado USA. <http://www.nsidc.org/data/nsidc-0079.html> (2229.01.99).

Constable, A.J., 2011. Lessons from CCAMLR on the implementation of the ecosystem approach to managing fisheries. Fish Fish. 12, 138-151.

Costa, D.P., Huckstadt, L.A., Crocker, D.E., McDonald, B.I., Goebel, M.E., Fedak, M.A., 2010. Approaches to studying climatic change and its role on the habitat selection of Antarctic pinnipeds. Integr. Comp. Biol. 50, 1018-1030.

Davison, A.C., Hinkley, D.V., 1997. Bootstrap Methods and Their Application. Cambridge University Press, Cambridge.

Delord, K., Besson, D., Barbraud, C., Weimerskirch, H., 2008. Population trends in a community of large Procellariiforms of Indian Ocean: potential effects of environment and fisheries interactions. Biol. Conserv. 141, 1840-1856.

Dinniman, M.S., Klinck, J.M., Smith Jr., W.O., 2011. A model study of circumpolar deep water on the West Antarctic Peninsula and Ross Sea continental shelves. Deep-Sea Res. Part II 58, 1508-1523.

Ducklow, H.W., Baker, K., Martinson, D.G., Quetin, L.B., Ross, R.M., Smith, R.C., Stammerjohn, S.E., Vernet, M., Fraser, W., 2007. Marine pelagic ecosystems: the West Antarctic Peninsula. Philos. Trans. Roy. Soc. B 362, 67-94.

Erickson, A.W., Hanson, M.B., 1990. Continental estimates and population trends of Antarctic seals. In: Kerry, K.E., Hempel, G. (Eds.), Antarctic Ecosystems. Ecological Change and Conservation. Springer-Verlag, Berlin-Heidelberg, pp. 253-264.

Fielding, S., Watkins, J., Cossio, A., Reiss, C., Watters, G., Calise, L., Skaret, G., Takao, Y., Zhao, X., Agnew, D., Ramm, D., Reid, K., 2011. The ASAM 2010 Assessment of Krill Biomass for Area 48 from the Scotia Sea CCAMLR 2000 Synoptic Survey. WG-EMM-CCAMLR-11/20, Hobart, Australia. <http://www.ccamlr.org/>

Forcada, J., Trathan, P.N., Reid, K., Murphy, E.J., Croxall, J.P., 2006. Contrasting population changes in sympatric penguin species in association with climate warming. Global Change Biol. 12, 411-423.

Forcada, J., Trathan, P.N., Murphy, E.J., 2008. Life history buffering in Antarctic mammals and birds against changing patterns of climate and environmental variation. Global Change Biol. 14, 2473-2488.

Forcada, J., Malone, D., Royle, J.A., Staniland, I.J., 2009. Modelling predation by transient leopard seals for an ecosystem-based management of Southern Ocean fisheries. Ecol. Mod. 220, 1513-1521.

Fraser, W.R., Hofmann, E.E., 2003. A predator's perspective on causal links between climate change, physical forcing and ecosystem response. Mar. Ecol. Prog. Ser. 265, 1-15.

Friedlander, A.S., Johnston, D.W., Fraser, W.R., Burns, J., Halpin, W.R., Costa, D.P., 2011. Ecological niche modeling of sympatric krill predators around Marguerite Bay, Western Antarctic Peninsula. Deep-Sea Res. Part II 58, 1729-1740.

Hedley, S.L., Buckland, S.T., 2004. Spatial models for line transect sampling. J. Agr. Biol. Environ. Stat. 9, 181-199.

Hewitt, R.P., Watters, G., Trathan, P.N., Croxall, J.P., Goebel, M.E., Ramm, D., Reid, K., Trivelpiece, W.Z., Watkins, J.L., 2004. Options for allocating the precautionary catch limit of krill among small-scale management units in the Scotia Sea. CCAMLR Sci. 11, 81-97.

Hill, S.L., Reid, K., Thorpe, S.E., Hinke, J., Watters, G.M., 2007. A compilation of parameters for ecosystem dynamics models of the Scotia Sea-Antarctic Peninsula region. CCAMLR Sci. 14, 1-25.

IOC, IHO, BODC, 2003. Centenary edition of the GEBCO Digital Atlas, Published on CD-rom on Behalf of the Intergovernmental Oceanographic Commission and the International Hydrographic Organization as Part of the General Bathymetric Chart of the Oceans, British Oceanographic Data Centre, Liverpool. <http:// www.bodc.ac.uk/products/bodc_products/gebco/>.

Kawaguchi, S., Nicol, S.G., Press, A.J., 2009. Direct effects of climate change on the Antarctic krill fishery. Fish. Manage. Ecol. 16, 424-427.

Kleiber, M., 1961. The Fire of Life. An introduction to animal energetics, Wiley, New York

Kuhn, C.E., McDonald, B., Shaffer, S.A., Barnes, J., Crocker, D.E., Burns, J., Costa, D.P., 2006. Diving physiology and winter foraging behavior of a juvenile leopard seal (Hydrurga leptonyx). Polar Biol. 29, 303-307.

Laake, J.L., Borchers, D.L., 2004. Methods for incomplete detection at distance zero. In: Buckland, S.T., Anderson, D.R., Burnham, K.P., Laake, J.L., Borchers, D.L., Thomas, L. (Eds.), Advanced Distance Sampling. Oxford University Press, Oxford, pp. 108-189.

Laws, R.M., 1984. Seals. In: Laws, R.M. (Ed.), Antarctic Ecology, vol. 2. Academic Press, London, pp. 621-715.

Lawson, G.L., Wiebe, P.H., Ashjian, C.J., Stanton, T.K., 2008. Euphausiid distribution along the Western Antarctic Peninsula-Part B: distribution of euphausiid aggregations and biomass, and associations with environmental features. Deep-Sea Res. Part II 55, 432-454.

Marques, F.F.C., Buckland, S.T., 2003. Incorporating covariates into standard line transect analyses. Biometrics 59, 924-935.

Mårtensson, P.-E., Nordøy, E.S., Blix, A.S., 1994. Digestibility of krill (Euphausia superba and Thysanoessa sp.) in minke whales (Balaenoptera acutorostrata) and crabeater seals (Lobodon carcinophagus). Br. J. Nutr. 72, 713-716. 
Meredith, M.P., King, J.C., 2005. Rapid climate change in the ocean west of the Antarctic Peninsula during the second half of the 20th century. Geophys. Res. Lett. 32 (L19604), 1-5.

Murphy, E.J., Watkins, J.L., Trathan, P.N., Reid, K., Meredith, M.P., Thorpe, S.E., Johnston, N.M., Clarke, A., Tarling, G.A., Collins, M.A., Forcada, J., Shreeve, R.S. Atkinson, A., Korb, R., Whitehouse, M.J., Ward, P., Rodhouse, P.G., Enderlein, P., Hirst, A.G., Martin, A.R., Hill, S.L., Staniland, I.J., Pond, D.W., Briggs, D.R., Cunningham, N.J., Fleming, A.H., 2007. Spatial and temporal operation of the Scotia Sea ecosystem: a review of large-scale links in a krill centred food web. Philos. Trans. Roy. Soc. B 362, 113-148.

Naumov, A.G., Chekunova, V.I., 1980. Energy requirements of pinnipeds (Pinnipedia). Oceanology 20, 348-350.

Nicol, S., Foster, J., Kawaguchi, S., 2011. The fishery for Antarctic krill-recent developments. Fish Fish. 12. http://dx.doi.org/10.1111/j.14672979.2011.00406.x.

Nicholls, K.W., Boehme, L., Biuw, M., Fedak, M.A., 2008. Wintertime Ocean conditions over the southern Weddell Sea continental shelf, Antarctica. Geophys. Res. Lett. 35 (L21605), 1-5.

Okes, N.C., Hockey, P.A.R., Pichegru, L., van der Lingen, C.D., Crawford, R.J.M., Grémillet, D., 2009. Competition for shifting resources in the southern Benguela upwelling: seabirds versus purse-seine fisheries. Biol. Conserv. 142, 2361-2368.

Øristland, T., 1977. Food consumption of seals in the Antarctic pack ice. In: Llano, G.A. (Ed.), Adaptations Within Antarctic Ecosystems. Proceedings of the 3rd SCAR Symposium of Antarctic Biology. Smithsonian Institution, Washington, DC, pp. 749-768.

Parkinson, C.L., 2004. Southern Ocean sea ice and its wider linkages: insights revealed from models and observations. Antarct. Sci. 16, 387-400.

Pichegru, L., Ryan, P.G., van Eeden, R., Reid, T., Grémillet, D., Wanless, R., 2011. Industrial Fishing, No-take Zones and Endangered Penguins. Biol. Conserv. doi: 10.1016/j.biocon.2011.12.013)

Pinheiro, J.C., Bates, D.M., 2000. Mixed-Effects Models in S and S-Plus. SpringerVerlag, New York.

R Development Core Team, 2009. R: A Language and Environment for Statistical Computing. R Foundation for Statistical Computing, Vienna, Austria. ISBN 3900051-07-0, URL. <http://www.R-project.org>.

Reilly, J.J., Fedak, M.A., 1991. Measurement of the body composition of living gray seals by hydrogen isotope dilution. J. Appl. Physiol. 69, 885-891.

Reilly, S., Hedley, S., Borberg, J., Hewitt, R., Thiele, D., Watkins, J., Naganobu, M., 2004. Biomass and energy transfer to baleen whales in the South Atlantic sector of the Southern Ocean. Deep-Sea Res. Part II 51, 1397-1409.

Rogers, T.L., Hogg, C.J., Irvine, A.B., 2005. Spatial movement of adult leopard seals (Hydrurga leptonyx) in Prydz Bay, Eastern Antarctica. Polar Biol. 28, 456-463.

Rolland, V., Barbraud, C., Weimerskirch, H., 2009. Assessing the impact of fisheries, climate and disease on the dynamics of the Indian yellow-nosed Albatross. Biol. Conserv. 142, 1084-1095.

Schiermeier, Q., 2010. Ecologists fear Antarctic krill crisis. Nature 467, 15.

Siniff, D.B., Stone, S., 1985. The role of the leopard seal in the tropho-dynamics of the Antarctic marine ecosystem. In: Siegfried, W.R., Condy, P.R., Laws, R.M. (Eds.), Antarctic nutrient cycles and food webs. Springer-Verlag, Berlin-Heidelberg, pp. $555-560$.

Siniff, D.B., Garrott, R.A., Rotella, J.J., Fraser, W.R., Ainley, D.J., 2008. Projecting the effects of environmental change on Antarctic seals. Antarct. Sci. 20, 425-435.
Southwell, C.J., de la Mare, W.K., Underwood, M., Quartararo, F., Cope, K., 2002. An automated system to $\log$ and process distance sight-resight aerial survey data. Wildlife Soc. Bull. 30, 394-404.

Southwell, C.J., 2005. Optimising the timing of visual surveys of crabeater seal abundance. Haulout behaviour as a consideration. Wildlife Res. 32, 333-338.

Southwell, C.J., Kerry, K.R., Ensor, P.H., 2005. Predicting the distribution of crabeater seals Lobodon carcinophaga off east Antarctica during the breeding season. Mar. Ecol. Prog. Ser. 299, 297-309.

Southwell, C.J., Paxton, C.G.M., Borchers, D.L., Boveng, P.L., de la Mare, W.K., 2008a Taking account of dependent species in management of the Southern Ocean krill fishery: estimating crabeater seal abundance off east Antarctica. J. Appl. Ecol. 45, 622-631.

Southwell, C.J., Paxton, C.G.M., Borchers, D., Boveng, P., Rogers, T., de la Mare, W.K. 2008b. Uncommon or cryptic? Challenges in estimating leopard seal abundance by conventional but state-of-the-art methods. Deep-Sea Res. Part II 55, 519531.

Southwell, C.J., Paxton, C.G.M., Borchers, D., Boveng, P., Nordøy, E.S., Blix, A.S., de la Mare, W.K., 2008c. Estimating population status under conditions of uncertainty: the Ross seal in East Antarctica. Antarct. Sci. 20, 123-133.

Stammerjohn, S.E., Martinson, D.G., Smith, R.C., Yuan, X., Rind, D., 2008. Trends in Antarctic annual sea ice retreat and advance and their relation to El NiñoSouthern Oscillation and Southern Annular Mode variability. J. Geophys. Res. 113 (C03S90), 1-20.

Thomas, L., Buckland, S.T., Rexstad, E.A., Laake, J.L., Strindberg, S., Hedley, S.L., Bishop, J.R.B., Marques, T.A., Burnham, K.P., 2010. Distance software: design and analysis of distance sampling surveys for estimating population size. J. Appl. Ecol. 47, 5-14.

Trathan, P.N., Fretwell, P.T., Stonehouse, B., 2011. First recorded loss of an emperor penguin colony in the recent period of Antarctic regional warming: implications for other colonies. PLoS ONE 6 (2, 1-11), e14738. http://dx.doi.org/10.1371/ journal.pone.0014738.

Trebilco, R., Halpern, B.S., Mills Fleming, J., Field, C., Blanchard, W., Worm, B., 2011 Mapping species richness and human impact drivers to inform global pelagic conservation prioritisation. Biol. Conserv. 144, 1758-1766.

Trivelpece, W.Z., Hinke, J.T., Miller, A.K., Reiss, C.S., Trivelpiece, S.G., Waters, G.M. 2011. Variability in krill biomass links harvesting and climate warming to penguin to penguin population changes in Antarctica. Proc. Natl. Acad. Sci. USA 108, 7625-7628.

Vaughan, D.G., Marshall, G.J., Connolley, W.M., Parkinson, C., Mulvaney, R., Hodgson, D.A., King, J.C., Pudsey, C.J., Turner, J., 2003. Recent rapid regional climate warming on the Antarctic Peninsula. Climatic Change 60, 243-274.

Whitehouse, M.J., Meredith, M.P., Rothery, P., Atkinson, A., Ward, P., Korb, R.E., 2008 Rapid warming of the ocean around South Georgia, Southern Ocean, during the 20th century: Forcings, characteristics and implications for lower trophic levels. Deep-Sea Res. Part I 55, 1218-1228.

Wood, S.N., 2006. Generalized Additive Models: An Introduction with R. Chapman and Hall/CRC.

Worthy, G.A.J., 2001. Nutrition and energetics. In: Dierauf, L.A., Gulland, F.M.D. (Eds.), CRC Handbook of Marine Mammal Medicine, second ed. CRC Press, Boca Raton, Florida, pp. 791-827. 